\title{
ŞAPKA MESELESI VE KILIK KIYAFET İNKILÂBI
}

\author{
Arş. Gör. Selâmi KILIÇ*
}

\section{a) Sapka ve Fes}

Bilindiği gibi II.Mahmut 1826 'da Yeniçeriliğin kaldırılması ile 1839 'da ölümü arasında büyük bir reform programına girişmiștir. Bu reformlarla, ondokuzuncu ve bir dereceye kadar yirminci yüzyıldaki Türk reformlarının izleyeceği ana hatları kurmuştur. II. Mahmut'un yapmış olduğu reformlar arasında sosyal ve kültürel alanda yapılan değişiklikler de yer almaktadir.

Eski zamanlardan beri, giysi ve her şeyden önce başlık, bir insanın dinini ve sosyal statüsünü belirttiği araçlardı. İslâm hukuku gerçekte hiç bir çeşit giysiyi yasaklamaz; fakat sayısız gelenekler Müslümanlardan, görünüşte bile kendilerini kâfirlerden ayırmalarını ve diğer her şeyde olduğu gibi, onların kıfyafetlerini taklitten kaçınmalarını ister. "Tanrı ve melekler inayetlerini Cuma namazında sarık saranlara verirler", "Sarıkla iki rekât namaz, sarıksız yetmiş rekâttan daha üstündür", "Bir milleti taklit eden, onlardan biri olur."

Peygambere atfedilen bu ve diğer bir çok benzer sözler, bir insanın kendi giyinme seklini terkedip diğer birini besimsemesinin bir ihanet ve dinden çıkma hareketi olduğu hakkındaki genel duygunun kuvvetlenmesine yardım etti. Müslüman olmayanların Müslüman kıyafetine girmesi yasaklanmıştı; Müslümanlar, Hıristiyan veya Yahudi kılığını almayı hayal bile etmezlerdi.

Bu nedenle, alelầde Müslüman Türk askerlerini, onların gözünde kâfirleri ayırdeden işaretleri, bir aşağılık nişânesini, benimsemeye razı etmek hiç de kolay bir iş değildi. Hepsinin içinde kabul edilmesi en güç olanı şapka idi; bugün bile bir çok Islâm ülkelerinde, başa örtülen şey muhâfazakârlığın son sığınağıdır. 1828 de Kuzey Afrika menşeli yeni bir başlık Sultana gösterildi ve onun beğenisini kazandı. Buna fes deniliyor$\mathrm{du}^{1}$.

* Atatürk Üniversitesi Atatürk Ilkeleri ve İnkılâp Tarihi Enstitüsü.

1. Bernard Lewis, Modern Türkiye'nin Doğuşu, Türk Tarih Kurumu Basımevi, Ankara, 1984, s. 100-101. 
Bütün medeni dünyanın kabul ettiği kılık ve kıyafet memleketemizde kabul edilmiş iken şapkanın kabulü bir asırdan beri mürtecilerin en çok inat ve mukavemet ettiği bir mesele olmuştur. Memleketimizde bir türlü şapka giyilmesine müsâdde edilmemiş ve bunun yerine, yine Avrupa mumûlatından fes giyilmiş, Milli Mücadele esnasında kalpak, fesin yerini tutmaya başlamıştı.

İkinci Mahmut zamanında Serasker ve mükerreren Kaptanı Derya olan Hüsrev Paşa, fesi memleketimize getirmeye sebep olmuştu. Kaptanı Derya iken gemilerdeki askerlere Tunus'dan getirdiği fesleri giydirmiş, Seraskerliğinde de İzmir'de teskil olunan bir taburun subay ve erlerine fes giydirerek İ́stanbul'a getirmişti. Eske Bâb-1 Seraskeri meydanında (bugünkü İstanbul Üniversitesi meydanı) bu tabura, İkinci Mahmut huzurunda talimler yaptırmıștı. İște fesin giyilmesi bu vasıta ile orduya intikal ederek, Tunus'a ellibin fes sipariş edilmişti.

Fesin resmi serpuş olarak kabulü 1244 (1828) senesi şevvalinin 6 sında neşrolunan elbise nizâmnâmesi ile takarrür etmişti.

Fes kadar orduların işine yaramayan bir serpuş olamazdı. Bazı kimseler, fesin estetik güzelliğini methetmişlerdi. Herhalde Hüsrev Paşa akıl edip fes yerine deniz ve karadaki askerlerimize Avrupa ordularında kullanılan kasketi giydirmiş olsaydı, yıllardan beri mürtecilerin dayandığı mesnetlerden en mühim olanı çoktan ortadan kalkmış olurdu² .

1829 'da kıyafet reformu sivilleri de kapsamına aldı. O yıl çıkarılan bir irade. çeşitli memur sınıflarında çeşitli vesilelerle giyilecek kıyafeti büyük ayrnntılarıyla belirtti. Genel olarak cübbe ve sarık yalnız ulemâya müsâde edildi. Diğer siviller için fes, zorunlu olarak diğer her çeşit başl1ğın yerini aldı; cübbe ve terliğin yerine de redingotlar, pelerinler, patolonlar ve siyah derili potinler geçti ${ }^{3}$.

\section{b) Mustafa Kemal Paşa'nın "Fes” İle İlgili Bir Hatırası:}

Kastamonu nutkunda, "şapka giymenin câiz olmayacağını söyleyenler vardır. Onlara diyeyim ki, çok gafilsiniz ve çok cahilsiniz ve onlara sormak isterim: Yunan serpuşu olan fesi giymek câiz olurda şapkayı giymek neden olmaz? " diyen Mustafa Kemal, Batı giyinişine karşı daima sempati duymuştur. Aynı zamanda Picardi manevralarına katılmak üzere Paris'e giderken Belgrat İstasyonu'nda arkadaşı Binbaşı Selahattin Bey'in başındaki fesi ile alay edilmesi, Mustafa Kemal'de, ulusal hiç bir 177.

2. Ali Fuat Cebesoy, Siyasi Hatıralar, C.II, Vatan Neşriyatı, Istanbul, 1957, s.176-

3. Lewis, Modern Türkiye'nin Doğuşu, s.102-103.

4. Atatürk'ün Şapka Devriminde Kastamonu ve Inebolu Gezileri, Derleyen: Mustafa Selim Imece, Türkiye Iş Bankası Kültür Yayınlan: 7, Ankara, 1975, s.64. 
yönü olmayıp II.Mahmut döneminde zorla giydirilmiş olan fese karş1 olumsuz bir tutum yaratmıs ve cumhuriyet döneminde şapka giyilmesinin psikolojik temelini oluşturmuştur ${ }^{5}$.

1910 yılında, Fransa'daki Picardi manevralarında ordu namına bulunmak üzere Paris'e doğru yola çıkmışlardı. İki arkadaştılar. İkisinin de ilk Avrupa gezisiydi. Bindikleri Şark Ekspresi daha Türk sınırlarından çıkar çıkmaz O, başındaki fesi çıkardı. Yol arkadaşı Binbaşı Selahattin Bey kapalı, muhâfazakâr bir subaydı. Tren Belgrat İstasyonu'nda beklerken Selahattìn Bey satıcı çocuklardan bir şeyler almak istedi. Başındaki kırmızı fesini hiç çıkarmıyordu. Satıcı Sırp çocukları evvela fesi ile alay etmeye başladılar. Sonra davranışlarını daha da ileri götürerek, bir şeyler haykırarak kaçıp gittiler. Selahattin Bey hâlâ, bu olaya vesile olan kırmızı fesini çıkarmayı milli bir gurur meselesi sayıyordu...

Mustafa Kemal Paşa bu olaydan çok sonra 1925'deki kıyafet inkılâbı ile kadın, erkek bir milletin hem iç hem dış görünüşünü yeniden yoğuracak ve Türkler Şark ruhunu ve Şark damgasını atıp, kendilerinin anlayış ve davranışlarına damgasını vuran Şarklı çemberinden çıkacaktı. Kıyafetleri ile de Batı âlemine katılacaklardı ${ }^{6}$.

\section{c) Klyafet Inkalabl* Öncesi "Sapka ve Fes" Hakkanda Yazalan Risâle ve Makaleler:}

Daha 1331 (1915) yılında Kılıçzâde Hakkı Bey, “Akvemü's Siyer Münâsebetiyle Yusuf Suad Efendi'ye Tahsisen Softa Efendilere Tamimen Son Cevap" adlı risâlesinde; kıyafetemizin milli olmadığını ve şapka giymenin İslâmiyet açısından hiç bir sakıncası bulunmadığını açıklarken şunları söylemektedir:

"Türkiye'de ittihâd-1 efkâr mevcut olmadığına en birinci delil esaslı ve milli bir kıyafetimizin mevcut olmaması yani herkesin istediği gibi giymesidir. İttihâd-1 efkâr, âsârını mutlaka her şeyde gösterir. Onun için bu cihet ihmâl edilmeyecek bir keyfiyettir. Müslümanlığın kıyafet-i mahsûsası olmadığına nazaran şapka giyilmesinde hiç bir zarar yoktur. Ecdâdımızın giydiği kavuklar hiç olmazsa memleketimizde i'mâl olunuyordu. Halbuki feslerimiz Avrupa'dan geliyor. Kendi metâmız olmadıktan sonra serpuş olarak herhangi bir şapkayı kabul etmeliydik. Hiç ol-

5. Şerafettin Turan, Atatürk'ün Düşünce Yapısını Etkileyen Olaylar, Düşünürler, Kitaplar, Türk Tarih Kurumu Basımevi,Ankara, 1989, s.4.

6. Şevket Süreyya Aydemir, Tek Adam-Mustafa Kemal, C.III (1922-1938) Remzi Kitabevi, Istanbul, 1985, s.234-235.

* "Kıyafet Inkılâbı ile ilgili olarak iki kanun çıkarılmıştır. Bunlardan biri 25 Kasım 1925 tarihli ‘Şapka İktisadı Hakkında Kanun' diğeri 3 Aralı 1934 tarihinde kabul edilen 'Bazı Kisvelerin Giyilemeyeceğine Dair Kanun'dur." (Bekir Sıtkı Yalçın-İsmet Gönülal, Atatürk Inkılabı, Kültür ve Turizm Bakanlığı, Ankara, 1984, s.99-204. 
mazsa bu suretle herkes başına daha süslü ve daha dayanıklı ve bilhassa daha faideli bir serpuş koymuş olurdu."

Abdullah Cevdet'te, İçtihâd'da yayınlanan "Şapka ve Fes" adlı makalesinde; Hayreddin Bey isminde bir Müslümanın başındaki şapkası ile İstanbul'da gezerken zâbita tarafından tutuklandığını ve bu olaydan önce Adliye Vekili Necati Bey'e, "Hükkânımızın serpuşlarından evvel serlerinin değişmesi lâzımdır" dediğini hatırlattıktan sonra, bizim hürriyet anlayışımız hakkında da şunları yazmaktadır:

"Mademki şu halimize ağyâr gülüyor, yara düşen ağlamaktır. Hürüz, hürriyet-i fikriyeye mâlik ve buna hürmetkârız diyoruz, aynı zamanda vatandaşın en küçüik hürriyetine tecâvüz ediyoruz. Hürendişleri de, zâhidleri de çağınyorum, fikirleri ve ruhları hür olanlan da, fikirleri ve ruhları ecdâtdan kalma hurâfât ve batıl itikadât zincirlerine müstagrık olanlan da hep çağınyorum, kemâl-i ihtirâm ile soruyorum:

"Avrupa ülkelerinden herhangi birisinde bir Avrupalı fes giyinse bu memleketlerin zâbıtası onu tevkif etmeyi hatırından geçirebilir mi? Değil yalnız fes, hatta bu fesin üzerine bir de âlâ bir yeşil yahut beyaz sarıta sarsa niçin bunu yapıyorsun demeye kimsenin hakkı ve haddi olur mu? Ey hür düşünenler ve ey mefkûreleri zincirbend olanlar! İşte biz hürriyeti bu kadar aşağı bir derecede anlıyoruz."

Abdullah Cevdet makalesinin devamında şapka ve fes ile ilgili olarak da şu ifadelere yer vermektedir:

"Mustafa Kemal Paşa, Türkiye'ye elhakk, bir istiklâl-i siyasi temin etti: Gümrüklerimize hâkimiz, ecnebiler memleketimizde Türk kanunlar1na tâbî, onlar, artık hem misafirimiz hem zorbamız olamıyorlar. Bunlar şüphesiz büyük ni'metlerdir ve bir kavmin şahsiyet-i levâzımındandır. Fakat kafalarımızın içindeki müstebid yılanları ne yapalım? Bugün Allah'ın Panama vadilerinde yetiştirdiği nâzik ve hafif bir nebattan yapılmış bir serpuşu giyindiği için bin gencin cumhuriyetimiz zâbıtası tarafından tevkif olunduğuna şahid-i dilhûn oluyoruz.

"Askeri serpuşlarımız bir şeye benzedi; fakat bu serpuşunda en lüzumlu kısmının, gözü şiddetli ziyâdan muhâfaza edecek kısmının terkedilmiş olduğunu görüyoruz. Canım bu fes ne ecdâdımızın ne de Müslümanlık itibârı ile Peygamberimizin serpuşu değildi... Fes Rumların serpuşudur, elyevm Yunanistan halkı ekseriyetle fes giyerler. Bir de farzedelim ki, hakikaten Türk kavmi Hz. Adem'in evlâdlarından ayrılarak bir şube-i kavmiye teşkil ettiği günden beri fes giyiyor, ecdâdımız fes gi-

7. Kılıçâdde Hakkı, Son Cevap, Yeni Osmanlı Matbaası, Istanbul, 1331(1915), s.49- 
yiyordu diye bugün aynı serpişi taşımayan bir vatandaşı mecbur edecek bir kanun mevcut olabilir mi?"

Görüldüğü gibi şapka giymenin yasak oldğu bir devirde kaleme alınan bir başka risâle ise, Süleyman Nazif' in Son Telgraf gazetesinden derleyerek broşür halinde yayınladığı "İmâna Tasallut Şapka Meselesi" dir? . Süleyman Nazif risâlesinin ilk sayfasında şunları yazmaktadır:

"Bu sahifeler (Son Telgraf) gazetesiyle intişâr ederken, (serpuş-1 milli) nâm meşrukiyle başımıza musallat olan fesin yerine şapkanın ikame edilmesi hakkında ne bir karar-1 resmi isdâr, ne bir temâyül-i hususi izhâr edilmişti. Gazetelerin perişan nüshaları arasında büsbütün zay' olmamak için şu tarihi mübâhase-i ilmiyeyi kitap şeklinde neşretmeyi münâsip gördük. ${ }^{10 "}$

Fatih Camii hocalarından İskilipli atıf Hoca, 12 Temmuz 1340 (1924) tarihinde yazmış olduğu "Frenk Mukallitliği ve Şapka" adlı risâlesinde; şapka, gayyar, zünnar, küstiç, gasli ve salibi ${ }^{11}$ küfür alâmeti ve gayr-1 müslim milletlerin en meşur işaretleri olarak gösterip, şapkay1; örfte küfür alâmeti, yani gayr-1 müslimlerin müslümanlardan ayrilmalarına alâmet olan baş kisvesi olarak tarif ettikten sonra, şapka, zünnar, giyyar, salib gibi ehl-i küfrün şiâr ve alâmeti olan şeyler giyinmek, kuşanmak, takınmak hususlarının şer'an yasak ve haram olduğunu belirtmektedir.

Atıf Hoca devamla; büyük fikıh âlimlerinin çoğunun, "kâfirlere mahsus ve onların kıyafet alâmeti olan şapkayı bir zaruret olmadan ve kendi arzusu ile giyinmek küfürdür" düşüncesinde olduklarını, fakat bazı fikıhçıların da; "kâfir milletlere ait olan şapkayı kendi arzusu ile giyen bir Müslüman onlara benzemiş ve onları taklit etmiş olduğu için günahkâr olursa da kâfir olmaz" fikrini savunduklarını söylemektedir.

Yazar daha sonra şapka hakkındaki görüşlerini açıklarken, şu ifadelere yer vermektedir:

"Şapka, zünnar, salib gibi şiâr-1 küfür alâmeti sayılan şeyleri iktisâ' ve ittihâz edinmekle şer'an yapılması emrolunan şeyleri, meselâ namaz

8. Abdullah Cevdet, "Şapka-Fes", İçtihâd, No.169, 1 Eylül 1924, s.3413-3414.

9. "Imâna Tasallut Şapka Meselesi" adlı bu risâle İskilipli Atıf Hoca'nın 12 Temmuz 1340(1924) tarihinde yazmış olduğu, "Frenk Mukallitliği ve Şapka" risâlesine reddiyedir. Risâlenin ilk sayfalarında Süleyman Nazif'in, Atıf Hoca'nın ve risâlesinin adını açıklamadan yazmış olduğu "Imana Tasallut" başlıklı makalesi yer almaktadır. Risâlenin diğer sayfalarında ise, Atıf Hoca'nın bu makaleye verdiği cevap ve yine Süleyman Nazif'in diğer bir makalesi bulunmaktadır." (Süleyman Nazif, Imâna Tasallut Şapka Meselesi, Matbaa-1 Tekfur, İstanbul, 5 Teşrinisânî 1341(1925), s.3-32.)

10. Süleyman Nazif, Imana Tasallut Şapka Meselesi, s.3.

11. Gayyar(gıyar), zünhar, küstiç(kesutiç), gasli ve salip kelimelerinin anlamları için bkz: Iskilipli Mehmet Atıf, Frenk Mukallitliği ve Şapka, Istanbul, 1340(1924), s.2223 . 
ve zekâtı terk ve yasak edilmiş olan şeyleri, meselâ zina ve hırsızlı̆̆ irtikâb beyninde fark nedir ki evvelkiler alâmet-i küfr ve emâre-i tekzî̉b addolunduğu halde ikinciler addolunmuyor diye bir sual irâd olunacak olursa cevabında deriz ki:

"Vakıa ikinciler de evvelkiler gibi şer'an memnû ise de hevesât ve şehevât-1 nefsâniye bunlan işlemeye fitraten sâiktir. Onun için kuvve-i şeheviyeleri akıllarına galip olan zümre-i beşer dinen memnû' olan müşteheyât-1 nesaniyeyi irtikâbdan halî kalmaz. İşte bunun için şâri' onları emâre-i tekzibden addetmemiştir. Fakat ehl-i küfre mahsus olan şiâr ve alâmeti irtikâb için böyle bir özür ve fitrî bir saik yoktur. Zirâ bu esasen nefsin arzu ve meyleylediği müşteheyât cümlesinden değildir. Şu halde bunu irtikâba sâik sû-i akideden başka bir şey olmadığı için şer'i şerif memnûât-1 şer'iyenin bu kısmını alâim-i küfr ve emâre-i inkầr add ile mürtekibinin küfrüne hükmetmiştir. ${ }^{12}$ "

İskilipli Atıf Hoca bu risâlesinde şapkanın küfür alâmeti olduğunu ve giyilmesinin İslâmiyet açısından sakıncası bulunduğunu açıkça belirtmektedir ${ }^{13}$. Tabiki bu düşünce Atıf Hoca'ya aittir. Diğer bazı Osmanlı aydınları hiç de atıf Hoca gibi düşünmüyorlardı. Nitekim daha öncede belirtildiği gibi, Kılıçzâde Hakkı Bey; "Müslümanlığın hususi bir kıyafeti olmadığına göre, şapka giyilmesinde hiç bir zarar yoktur" derken, Abdullah Cevdet'te: Fesin ne ecdâdımızın ne de Müslümanlık itibân ile Peygamberimizin serpuşu olmadığını belirterek, şapkayı Panama vadilerinde yetişen nâzik ve hafif bir nebattan yapılmış başlık olarak tanımlamaktadir.

İskilipli Atıf Hoca'nın "Frenk Mukallitliği ve Şapka" adlı risâlesine yukanda da temas edildiği üzere, Süleyman Nazif cevap vermekte ve şu hususları dile getirmektedir:

"Yeni intişâr eden bir risâleye göre, muharriri ders-i âmm efendi ile kendi kıyafetindeki hoca efendilerden başka, her mümin, hepimiz-hâşâsümme hâşâ-kâfirmişiz. Hey'et-i mecmûasının zihinlerde bırakmak istediği fikir ve kanaat şudur: "Biz dinimize kalbimizin tasdikiyle, lisanım1zın ikrârı kadar, feslerimizin sarığı ve püskülü ile de merbutuz. El-iyazü billah..." Şapkayı diline ve kalemine dolayan muharrir niçin frengin gömleği ile boyunbağını hatıra getirmiyor? Hatta frengin bir kisvesini frenk gömleği şekline soktuktan sonra sırtımıza geçiriyoruz. Sarıklı birçok efendi, frenk gömleğini cübbesinin altında ve iman evi addettiği sinesinin üstünde pîpervâ taşıyor.

12. Iskilipli Mehmet Atıf, Frenk Mukallitliği ve Şapka, s.22-26, 30-31.

13. "Frenk Mukallitliği ve Şapka" adlı kitabın sahibi Îskilipli Atıf Hoca İnkılâbı ile ilgili gerici eylemlerden suçlu görülerek -Îstiklâl Mahkemesi kararıyla- 4 Şubat 1926 tarihinde Ankara'da idam edilmiştir. (Prof.Dr. Utkan Kocatürk, Atatürk ve Türkiye Cumhuriyeti Tarihi Kronolojisi (1918-1938), Türk Tarih Kurumu Basımevi, Ankara, 1983, s.450. Ayrica bkz: Ergün Aybars, İstiklâl Mahkemeleri, C.II, Izmir, 1988, s.416). 
"Zünnar ile salibi şapka ile bir tutmak kelimenin hem Arapça ma'nâsı, hem Türkçe mefhûmuyla haltetmektir. Şapkada alâmet-i küfr olacak bir şey yoktur. Bu risâlenin dar düşünceli muharriri ne hak ile beni ve benimle beraber, la-akall yirmi milyon Müslümanı küfr ile şâibedar göstermeğe çalışıyor.

"Muharrir risâle, şapkayı diyânet ve milliyet alâmeti addediyor. Yanlış. Avrupa'da milliyet ve diyânetleri muhtelif akvâm ve cemâatin serpuş1 müştereki şapkadır; ve Yahudilerin ki başka, Hıristiyanların ki başka değildir. Binaenaleyh her fes giyen Müslüman olmadığı gibi, her şapka giyen de -lehülhamd!.. kâfir degildir.

"Risâlenin muharriri, tertip ettiği kıyaslara takılarak ve âdeta sürüklenerek, nihayet şapka, zünnar ve salib gibi küfür alâmeti saydığ1 şeyleri, zinâ ve hırsızlıktan daha aşağı, daha hafif ve ma'zûr gösteriyor. Şapka küfür değil, mekrûh değil, fes gibi, tâc gibi, külâh gibi, bîgünah bir serpuştur. Malta mahbuslarının arasında bir kısmı vardı ki, namazlarını edâ eder ve o sıcak iklimde sehr-i ramazanın bir gününü nakz-1 sıyâm ile mahsun bırakmazlardı. Sokağa çıkmaya me'zûn oldukları zaman, bu vatanperverler, şapka giyiyorlardı. Fatih camii' nin ve bütün dünyanın ders-i âmmları emin olsunlar ki, Dürrizâde'nin sarığı şer'i şerifi İngilizlerin ayakları önüne hakir bir seccâde gibi yayarken, Malta'nın günde beşkere Allah'a ve yalnız Allah'a secde eden alınlar üstündeki şapkalan din ve vatan aşkıyla tutuşacak derecelere gelirdi.

"Şapka, fes, sarık: Efrâd-1 ümmeti böyle şeylerle Din-i İslâm'a rabtetmek o dine hakarettir. Ben dinime ne başımdaki esyayı hasise ile merbutum, ne ayağımdaki şeylerle. Müslüman doğduğum gibi Müslüman öleceğim. Kendi ayağındaki frenk kundurasını mübâh ve müstehabb gören Hoca Efendi, başka bir kimsenin başındaki şapkaya ne hakla ve ne haddle küfr ve dinsizlik damgasını yapıştırıyor?... Medresedeki çömezlik devrini itmâm etmeden Anadolu'da vaaz ve irşâda çıkan bir sarıklı "ruh-1 ecdâda mugayir kanunlara isyan etmeli" sözüyle iğrenç cehâletini kasaba kasaba, köy köy kusuyor. Bugünde bir ders-i âmm çıkmış, birçok Müslümanın tepeden tırnağa kadar kâfir bulunduklarına ilâmlar neşrediyor. artık yeter. Bu halk üç beş cahilden ibâret değildir. Din büyük, din mukaddestir. Biz onu başımızda, sırtımızda, ayağımızda değil, dimağımızda, kalbimizde, vicdan ve imânımızda taşımalıyız. Ümmet-i Muhammedi düşünen ve ümmetin hâlâsı için ömrünü son nefesine kadar i'tâbeden merhum Pierre Loti'nin masum şapkası, Bursa'yı çiğneyen Yunan ordusuna en şenî temelluklarda bulunmaktan ve Eskişehir'in sükût ettiği gün Kral Yorgi' yi tegrafla tebrik etmeden hayâ etmeyen Bursa Müftisi ders-i âmm Ömer Fevzi Efendi'nin yeşil sarığından daha muhterem ve daha mübârektir. ${ }^{14}$ ",

14. Süleyman Nazif, Imâna Tasallut Şapka Meselesi, s.4-10. 
Atıf Hoca, Süleyman Nazif' in "İmâna Tasallut" başlıklı makalesine cevap verirken; "makale ilim ve mantık dairesinde yazılmıs bir tenkitnâme olsaydı, ilmî cevap verdikten başka samimi teşekkürâtımı arz ve takdim ederdim" dedikten sonra, "Süleyman Nazif' in, (bugünde bir ders-i âmm çıkmış birçok Müslümanın tepeden tırnağa kadar kâfir bulunduklarına ilâmlar neşrediyor. Artık yeter. Bu halk üç beş cahil mutaassıbın keyfine kulluk edemez.) sözüyle iftirâ ettiğini, risâlesinde Müslüman olan hiç bir ferdin küfrüne dair bir ma'nânın bulunmadığını" yazmaktadır.

Atıf Hoca, makalesinin devamında hem Süleyman Nazif'e cevap vermekte hem de asıl konu ile ilgili görüşlerini açıklamaktadır:

"(Şapkada alâmet-i küfr olacak bir şey yoktur. Şapka küfr değil, haram değil, mekrûh değil, fes gibi, külâh gibi, tâc gibi bîgünah bir serpuştur. Pierre Loti'nin masum şapkası...) Bu sözleriyle şapka hakkındaki akide-i esâsiyesini izhâr etmiş, sarih ve kat'i fetvasını vermiş̧ir. Halbuki risâlede şapkaya dair mübâhisi fetevâ-1 Hindiye, Kadıhan, Muhid-i Burhanî gibi ketb ü mu'tebere-i fikhiyeden ve ulûm-1 şer'ide ihtisâsları bulunan eimme-i din ve fukuhâ-i zevi'l ihtirâmın kitaplarından ahz ile tercüme ettim. Ruh-1 meseleye kendiliğinden bir şey ilâve etmedim. Ve edillesiyle beraber meseleyi kemâl-i vuzûhla beyân ettim. Fakat, bahs ilmî olduğu için hin-i mütâlaada biraz dikkat ister.

"İlm-i fikıhta erbâb-1 ihtisâstan bulunan ve sözleri her vechle şâyân1 i'timâd olan zevât-1 kirâmın sözlerine mi ehl-i İslâmın i'timâd ve imân etmesi vâcib olur, yoksa kendisi i'tiraf ettiği vechle yirmiden kırkbeş yaşına kadar şekk vadisinde dolaşan ve izlâl vadisinde yaşayan, onbir senelik İslâmiyeti zamanında da zaruriyât-1 diniyeye saldırmaktan geri durmayan Süleyman Nazif Bey'in şapka hakkında vermiş olduğu hükümlere, fetvalara mı i'timâd etmeleri lâzım geleceğine dair verilecek hükmü yine efkâr-1 âmmeye havale ederim.

"Süleyman Nazif Bey böyle yarım ma'lûmâtla ahkâm-1 İslâmiyeye dair indî fetvalar vermeye kalkışacağına aradan hürmetle çıkıverse daha fazla hıdmet etmiş olur. ${ }^{1{ }^{\prime \prime}}$

Süleyman Nazif, Atıf Hoca'nın bu makalesine cevap olmak üzere bir makale daha kaleme almış ve bu yazısında, kendisine "Imâna Tasallut" makalesini yazdıran risâlenin ve yazarının adını açıkladıktan sonra, şunlan yazmıştır:

"Bu bahsin durup dururken ortaya atılmasında ne lüzum, ne münâsebet vardı? Frenk masasının başında, frenk sandalyesine oturup, frenk kalemiyle, Frenkistan'dan gelen, başlan frenk markalı, içleri frenk

15. Süleyman Nazif, Imâna Tasallut Şapka Meselesi, s.11-18. 
fligranlı kâğıda yazı yazmak; omuzdan ayağa kadar frenk libas ve çamaşılanını giyinmek, çatalla bıçakla yemek, tramvaya, otobüse, vapura, șimendüfere binmek günah olmuyor, sevap oluyar da, başa Rumlardan yüz sene evvel almış olduğumuz fese bedel şapka geçirmek küfür addediliyor. İmâm Ahmet ve Ebû Davut değil, İmâm-1 Âzam bunu iddiâ etse -ki etmemiştir- yine kabul etmem. Mütevâtiren sâbit olan Hadis-i celile-i Nebevîye'den mâ-adâ, kitaplara hadis nâmıyla geçen sözlerden bir çoğuna benim imânım yoktur. Ben Allah'a, Kur'ân'a ve Kur'ân'da mezkûr olan kitaplarla, Peygamberlere imân etmekle mükellefim. (Imâm Ahmet), (Ebû Davut) ve emsâli bizim gibi beşer ve yine bizim gibi hatâ etmeleri muhtemeldir.

"Ehl-i sünnet mezhebine mensup olduğu cihetle kelime-i şehâdeti söyleyen herhangi bir şahısa isnâd-1 küfr etmeye akidesinin müsâid bulunmadığını iddiâ eden bir adam, binlerce milyonlarca ümmeti, düşünmeksizin tekfîr etmek cüretinde bulunuyor ve bulunmuş da haberi yok.

"Hakk-1 tahrîm, ne İskilipli Atıf Efendi'nin, ne fukahânın, ne muhaddis ve müfessirlerin, hattâ ne de Peygamberindir. Hakk-1 tahrîm Allah'ındır!.. Böyle iken ve Cenâb-1 Hakk zinâ ile hırsızlığı Kur'ân-1 Kerimi'nde açıkça tahrîm etmişken, Atıf Hoca'nın hakkında sarîh hiç bir yasak bulunmayan bir serpuştan, o iki büyük günahı daha hafif göstermesini açıklamaktan acizim. Atıf Efendi'den değil, fukahâdan değil, Ebû Hanife'den böyle bir söz işitsem, v'Allah-ül-âzim derhal mezhebimi terkederim. ${ }^{16 "}$

\section{d) Mustafa Kemal Paşa'nın "Şapka" Nutku ve Sonrası:}

Mustafa Kemal 24 Ağustos 1925 tarihinde Kastamonu halkının daveti üzerine "Kastamonu Gezisi" ne çıkmıştır. Gazi bu gezisi esnasında yaptığı çeşitli konuşmalarında; şimdiye kadar yapılan ve yapılacak olan inkılâpların hedefini, "Türkiye Cumhuriyeti halkını tamamı ile ve bütün şekilleriyle medenî bir toplum haline getirmektir" diye açıklamıştır.

Kurtarıcımızın, Kastamonu'ya gelişlerinde ve karşılanması sırasında ilk defa panama şapka ile görünmesi, halkımızı başı açık selâmlaması üzerine, o sırada Kastamonu Valisi bulunan merhum Kıbrıslı Fatin Bey ile Kastamonu Milletvekili Ali Rıza ve Mehmet Beyler ve bir kısım aydın Kastamonulular alelacele terzilere beyaz renk kumaştan şapkaya benzeyen serpuşlar yaptırmışlar ve başlarına giymişlerdi. Gazi'nin Kastamonu Illi içinde yaptığı gezilerinde bu serpuş, Vali Fatin Bey'in kâh başında kâh elinde görülürdü ${ }^{17}$.

16. Süleyman Nazif, Imana Tasallut Şapka Meselesi, s. 19-32.

17. Mustafa Selim Imece, Kastamonu ve Inebolu Gezileri, s.20. 
Gazi, Kastamonu Belediyesi'nde, şehrin esnaflarını temsil eden bir grubu, daha serbest konuşabilmeleri için hep birlikte salona davet etmiştir. Bu sırada bir terziye elbiselerini göstererek:

- Bu elbiseler herhalde ucuzdur. Kumaşı da düz. Uluslararası kıyafet midir? Diye sorunca,

- Evet, uluslararası, diye cevap vermiş,

- O halde bu elbiseler hem ucuz ve hem de yerli malidır. Aynı elbiseye kumaşından bir de serpuş yaparsınız, demiştir.

Başka bir esnafa da "fesini göster bakalım" dedi. Fesinin altından takke çıktı. İ̧inde takke, üzerine abani sarık, sonra fes "bunların hepsinin parası yabancıya gidiyor. Bunları söylemekten amacım şudur" dedikten sonra şöyle devam etti:

"Biz her bakımdan uygar insan olmalıyız. Çok acılar gördük. Bunun nedeni dünyanın durumunu anlamayışımızdır. Fikrimiz, düşüncemiz tepeden tırnağa kadar uygar olacaktır..."

Mustafa Kemal daha sonra, belediye binasından ayrilarak, vilâyete, hükümet dairesine, gitmiştir. Valinin odasında savcıyı ve yargıçları, memurları, lise müdür ve öğretmenlerini kabul ediyor; daire başkanlarından ilin durumu hakkında geniş bilgi alıyordu.

Memurlar başı açık olarak Gazi'nin yanına girmiş; başında sarı̆̆ı olan Müftü Efendi de sarığını çıkarmış, başını açmıştı. Gazi Müftü'ye, kisvenin tarihçesini sordu. Müftü de, kisvenin İslâmiyet'te şeklini, çıkar ve gereksinmeye tabi olduğunu, cübbenin hangi tarihte kimler tarafından ne amaçla giydirildiğini açıkladı. Ateşe tapanlardan alınan inek, yeni sahibine sütünü sağdırmazsa $\mathrm{o}$ adamın ateşe tapan kılığına girebileceği hakkındaki hükmünü söyledii ${ }^{18}$.

25 Ağustos 1925 salı günü Kastamonu'dan İnebolu'ya geçen Gazi tarihi "Şapka Nutkunu" bu ilçede yapmıştır ${ }^{19}$. Mustafa Kemal bu nutkunda;

"Ey memleketini seven ve memleketi, milleti için hayatını fedâdan çekinmemiş bulunan klymetli vatandaşlar! Hep beraber bütün cihâna sarih ifade edelim ki, bunca inkılâbâtın şuurlu kahramanı olan bu millet, medeniyet güneşinin bütün hararetini almıştır" dedikten sonra, konuşmasının devamında şunları söylemiştir:

18. Imece, Kastamonu ve Inebolu Gezileri, s.25-27.

19. "O gün Inebolu tarihi, heyecanlı ve mesut günlerinden birini yaşadı. Mustafa Kemal, şapka nutkunu Inebolu Türk Ocağı'nda 27 Ağustos 1925 günü söylemiştir." (Imece, Kastamonu ve Inebolu Gezileri, s.56.) 
“Efendiler, Türkiye Cumhuriyeti'ni te'sis eden Türk halkı medenîdir. Tarihte medenîdir, hakikatte medenîdir. Fakat medenîyim diyen Türkiye Cumhuriyeti halkı; fikriyle, zihniyetiyle medenî oduğunu isbât ve izhâr etmek mecburiyetindedir. Ve-l, hâsıl medenîyim diyen, Türkiye'nin, hakikaten medenî olan halkı başından aşağıya vaz'ı haricisiyle dahi medenî ve mütekâmil insanlar olduğunu fiilen göstermeye mecburdurlar. Bu son sözlerimi vâzıh ifade etmeliyim ki, bütün memleket ve cihân ne demek istediğimi suhûletle anlasın. Bu izâhâtımı hey'et-i âlinize, hey'et-i umûmiyeye bir sualle tevcih etmek istiyorum, soruyorum:

"Bizim kıyafetimiz millî midir? (hayır sadâları). sadâları).

"Bizim kıyafetimiz medenî ve beynelmilel midir? (hayır, hayır

"Size iştirak ediyorum. Tabirimi ma'zûr görünüz. Alt1 kaval üstü şişhâne diye ifade olunabilecek bir kıyafet, ne millîdir ve ne de beynelmileldir. O halde kıfayetsiz bir millet olur mu arkadaşlar? Böyle tavsif olunmaya razı mısınız arkadaşlar? (hayır hayır kat'iyyen sesleri). Çok kıymetli bir cevheri çamurla sıvayarak enzâr-1 âleme göstermekte ma'nâ var mıdır? Ve bu çamurun içinde cevher gizlidir, fakat anlıyamıyorsunuz demek musip midir? Cevheri gösterebilmek için çamuru atmak elzemdir; tabiîdir... Arkadaşlar, Turan kıyafetini araştırıp ihyâ' eylemeye mahall yoktur. Medenî ve beynelmilel kayafet bizim için çok cevherli, milletimiz için lâyik bir kıyafttir. Onu iktisâ' edeceğiz. Ayakta iskarpin veya fotin, bacakta pantolon, yelek, gömlek, kıravat, yakalık, caket ve bittab' bunların mütemmimi olmak üzere başta siperi şemsli serpuş, bunu açık söylemek isterim. Bu serpuşun ismine şapka denir. Redingot gibi, bonjur, smokin gibi, işte şapkanı! !

"Buna câiz değil, diyenler vardır. Onlara diyeyim ki, çok gafilsiniz ve çok câhilsiniz ve onlara sormak isterim:

"Yunan serpuşu olan fesi giymek câiz olur da şapkayı giymek neden olmaz ve yine onlara, bütün millete hatırlatmak isterim ki, Bizans papazlarının ve Yahudi hahamlarının kisve-i mahsûsası olan cübbeyi ne vakit, ne için ve nasıl giydiler? ${ }^{20 "}$

Gazi Mustafa Kemal Paşa, 30 Ağustos 1925'de Kastamonu Halk Firkası binasında da bir nutuk söylemiş ve çeşitli konulara değindikten sonra kıyafet meselesine geçerek demiştir ki:

“İnebolu'da ve diğer bazı yerlerde söyledim. Bugünün meselesi gibi mütâlaa edileceğinden burada da bahsetmek isterim. Her milletin olduğu

20. Atatürk'ün Söylev ve Demeçleri (1918-1937), C.II, Türk İnkılâp Tarihi Enstitüsü Yayınları: 1, Türk Tarih Kurumu Basımevi, Ankara, 1989, s.220-221; Imece, Kastamonu ve Inebolu Gezileri, s.62-64. 
gibi bizim de millî bir kıyafetimiz varmıs, fakat gayri kabil-i inkârdır ki taşıdığımız kıyafet o değildir. Hatta millî kıyafetimizin ne olduğunu bilenler içimizde azdır bile. Meselâ karşımda kalabalığın içinde bir zât görüyorum (eliyle işaret ederek). Başında fes, fesin üstünde bir yeşil sarık, sirtında bir mintan, onun üstünde benim sırtımdaki gibi bir caket, daha alt tarafını göremiyorum. Simdi bu kıyafet nedir? Medenî bir insan bu alelâcaib kıyafete girip dünyayı kendine güldürür mü? (Evet, güldürür sadâlan)."

Gazi kıyafet hakkında geniş izâhât ve malûmat vererek sözü şu neticeye getirdi:

"Devlet memurlan büțün milletin kıyafetlerini tashih edecektir. Fen, sıhhat nokta-1 nazarından amelî olmak itibâriyle, her nokta-1 nazardan tecrübe edilmiş medenî kıyafet iktisâ' edecektir. Bunda tereddüde mahall yoktur. ${ }^{21}$ "

Mustafa Kemal Paşa'nın Kastamonu Gezisi ve çeşitli yerlerde yaptığı konuşmaları gazetelere de yansımıştır. Nitekim, Cumhuriyet Gazetesi Kastamonu gezisinin amacına ulaştığını yazarken, sütunları arasında aşağıdaki satırlara yer vermektedir:

“Büyük Gazi'nin Kastamonu'dan yükselen sesi Türk ilinin her tarafında asırlardan beri tesbit edilemeyen kıyafetimizi iki ay zarfında tamamen değiştirmiş bulunuyor.

“Kastamonu'da kimbilir ne zamandan kalma ma'nâsız bir görenek te'siri, fesin üzerine sark sarmak âdet olmustu. Bundan halk bilhassa köylü cidden matazarrır oluyordu. Meselâ alelâde bir fes yüzelli kuruşa alınıyor, köylüi için ona muhakkak elli kuruşluk bir de yazma sarmak mecburi idi. Halbuki köylülerimiz şapkalarını elli ile yüz kuruş arasında tedarik edebiliyorlar... Ne kadar mesuduz ki, vatanı büyük bir bâdireden, Türklüğü büyük ve muhakkak bir felâketten askerî ve siyasi dehâsı ile kurtaran Gazi bir işareti ile bizi medenî insan ssekline soktu. Biz zaten medenî idik. Fakat medenî kuyafeti daha evvel kabul edenler bizi acâib k1yafetimizle medeniyetten, medenî insanlıktan, uzakta görüyorlardı.

"Şimdi baştan nihayete, tepeden tırnağa kadar medeniyiz. Hükümetimiz en asî́ bir şekl-i idâre, kıyafetimiz medenî ve asrî bir kıyafet... Kastamonu halkı Gazi'nin medenî kıyafet hakkındaki işeretini çok memnuniyetle karşılamış ve 29 Teşrinievvel (29 Ekim bayramından itibâren

21. Atatürk'ün Söylev ve Demeçleri, C.II, s.226. Aynca bkz: İmece, Kastamonu ve Inebolu Gezileri, s.84. 
Kastamonu'da tek fesli kalmamış, bütün halk bilâ-istisnâ şapka giymiştir. 22 "

Mustafa Kemal Paşa, Kastamonu seyahatinden Ankara'ya şapkalı döndü. Şehir yakınlarında kendisini karşlamaya gidenlerden Yunus Nadi'nin şapkasını beğenerek kendisinin ki ile değiştirdi. İlk havadisi duyar duymaz başına şapka giyerek İstiklâl Mahkemesine geldiği için "Vakit" muhabirini huzurundan kovan ve hapsetmeye kalkışan rahmetli Afyon Milletvekili Ali Bey de, şapkası ile karşılayıcılar arasında idi.

Bir hayli sonra, meselâ İzmir gibi aydın çevreler varken, ilk şapkayı niçin Kastamonu taassubu içinde giydiğini Mustafa Kemal'den sormuştum. Şu cevabı verdi:

- İzmir tarafı halkı beni birçok defa gördü. Eğer orada şapka giysem, bana değil, şapkama bakarlardı. Beni ilk defa görenler ise şapkamla olduğum gibi kabul ettiler ${ }^{23}$.

Mahmut Esat (Bozkurt)'ta "Atatürk İhtilâli" adlı kitabında; "Şapka, medenî kanun v.s. bunlar ilân edilen yeni Türk rejiminin gerekimleridir. Şapka giymek ne demek? Bütün ilerlemelerin başında bu mu gelir? Evet ve bunda hiç şüphe edilmemelidir. Gerçi fes giymek bir mesele değildir. Fakat mesele fese bir kutsallık veren onu çıarıp atmayı, mukaddesâta hakaret sayan zihniyettedir. Şapka giymek, işte böyle sakat bir zihniyeti yerlere, çamurlara çalmak için gerekliydi ve gereklidir. Şapka giymekle, ilerlemelere mâni' olan bu kara engel söküldü, yıkıldı, yerin dibine geçirildi. Büyük yürüyüş yolları açıldı" diyerek, düşüncelerini belirttikten sonra, bir de hatırasını nakletmektedir:

"Atatürk bir gün, lütfen, bu husustaki fikrimi sormuşlardı. O sırada Musul işi, aleyhimize sonuçlandığı için, rahmetli hayli sıkıntılı idi.

"Şu cevabı vermek cesaretinde bulundum: Şapka giymek, bu millet hesabına bir Musul fethinden üstündür! Atatürk hafifçe gülümsedi ve başını bir kaç defa eğerek beni taltif etti. ${ }^{24}$,

“Türkiye'de Demokrasi İnkılâbı" adlı kitabın yazarı Mehmet Safvet; “Türk Cumhuriyeti ile gelen diğer bir inkılâpta içtimaî inkılâptır. Bu inkılâpla âile hukuk ve teşkilatımızı, bilumûm vatandaşlar arasındaki münâsebet-i içtimaîyeyi eski köhne sahalardan kurtararak yepyeni ve aklî sahalara sokmuş oluyoruz. Bu miyanda serpuşlarımızı da değiştirip beynelmilel bir serpuş kabul edişimiz kıyafetimizde şâyân-1 takdir bir Avrupalılık hatvesidir. 25" derken, Celal Nuri (İleri) de "Türk İnkılâbı" adlı eserinde şunları yazmaktadır:

22. Cumhuriyet, 21 Teşrinisani 1341 (21 Kasım 1925), No: 552.

23. Falih Rıfkı Atay Çankaya, Kral Matbaası, Istanbul, 1984, s.434.

24. Mahmut Esat Bozkurt, Atatürk thtilâli, s.154-155.

25. Mehmet Safvet, Türkiye'de Demokrasi Inkılâbi, Kütüphâne-i Sûdi Istanbul, 1928, s. $44-45$. 
"Alâfranga kıyafetin kabulü efrâdımızı hayliden hayliye intizâma sevketti. Baş açık olmadan evvel hiç bir kimse saçına itibâr etmezdi. Şapkanın kabulünden sonra ise, vaktiyle tarağın ismini bilmeyen yobazlar tuvalete rağbet etmişlerdir. ${ }^{26}$ "

Yurt dışındaki Halide Edip (Adıvar) Hanım da, "Şapka Kanunu"nun bu dönemde girişilen devrimlerin ilki ve en gözalıcısı olmakla birlikte, aynı zamanda en beyhude ve sathîsi olduğunu söylemektedir. Ona göre, "devrimler arasında en ciddi muhlefeti yaratan" bu yasaya sokaktaki adamın karşıtlığı, yasayı yapanlardan gerçekte daha çok Batılıydı ${ }^{27}$.

\section{Kabulï:}

e) Nurettin Paşa'nın İtirazı, Bazı Hadiseler ve Şapka Kanununun

"Şapka İktisâsı" hakkındaki kanun teklifi 16 Ekim de Konya Mebusu Refik Bey ve arkadaşlarınca Meclis Başkanlığı'na verildii ${ }^{28}$. Teklif ilgili komisyonlardan geçtikten sonra, Genel Kurul'a geldi ve Refik Bey'in teklifi, 25 Ekim de görüşülmeye başland ${ }^{29}$.

Umûmî serpuşun şapka olmasında ve bu kanunun müttefiken kabul edilmesinde Meclis birlik yapmış iken müstakil Bursa Mebusu Nurettin Paşa bu kanunun aleyhinde uzun bir takrir vererek ${ }^{30}$, gerek bu kanunun ve gerekse hükümetin kararnâmesinin Teşkilât-1 Esâsiye Kanunu'na muhalif olduğunu iddiâya kalkışmış ise de, bu iddiâsı Meclis tarafından şiddetle karşılanmış; şahsi sözlerin ve tecâvüzlerin teâtisine sebep olmuştu. Paşa itirâzının esas mesele hakkında olmadığını söylemiş, kanunun Teşkilât-1 esâsiye Kanunu'nun bir çok maddesine muhalif olduğunu iddiâ etmiş ve Meclis'deki hukukşinâsları bu babda söz söylemeye davet etmişti. Ondan sonra bir daha kürsüye çıkmamıştı.

Başta Adliye Vekili Mahmut Esat Bey olmak üzere bazı hukukşinâs mebuslarda Paşa'nın teklifini esasından cerh ve reddetmişlerdi ${ }^{31}$.

Nurettin Paşa'nın bu teklifi sert cevaplara yol açtı. İlk söz alan Konya Mebusu Refik Bey, milletin kabul ettiği, bütün medenî milletlerin 152.

26. Celal Nuri (Ileri), Türk Inkılâbı, Ahmet Kâmil Matbaası, Istanbul, 1926, s.151-

27. Mete Tuncay, Türkiye Cumhuriyeti'nde Tek Parti Yönetiminin Kurulması (1923-1931), Yurt Yayinları:1, Ankara, 1981, s.151.

28. "Şapka Iktisâsı hakkında Konya Mebusu Refik Bey ve Rüfekasının 2/479 numarahı teklif-i kanunisi. Adliye ve Dahiliye mazbatalan için bkz: Yalçın-Gönülal, Atatürk Inkılâbı, s.99-101 ve TBMM. Zabıt Ceridesi, 25 Kasım 1341(1925), c.XIX, Devre: II,TBMM. Matbaası, Ankara, 1960, s.247-248."

29. Aybars, Istiklâl Mahkemeleri, C.II, s.399.

30. Bursa Mebusu Nurettin Paşa'nın takriri hakkında bkz: Yalçın-Gönülal, Atatürk Inkılâbı, s.102-105 ve Z.C. II/XIX, 25 Kasım 1341(1925), s.249-250.

31. Cebesoy, Siyasi Hatıralar, C.II, s.177-178. 
giydiği şapkaya karşı çıkmanın Nurettin Paşa'nın seçim bölgesi olan Bursa halkının eğilimini yansıtamayacağını, Meclis'den çıkan kanunların milletin varlığını korumak esasına dayandığını; daha sonra söz alan Adalet Bakanı Mahmut Esat Bey, kanunun Anayasa'ya aykırı olmadığını, Japonya'da mebusların kendi meclislerinde silindir şapka giymek zorunda olduğunu belirttiler. Ağaoğlu Ahmet Bey, "şapka meselesinin Anayasa ile ilgili olduğunu işitirken utandım. Şapkanın, gömleğin, redingtonun, mendilin Anayasa ile ne ilgisi vardır? Bu ne anlayıştır?... Anayasa bir milletin hayatının esas çizgilerini tertipler ve düzenler, yaşayışın ilkelerini düzene koyar ve dayandığı temelleri tertipler ve düzenler." dedikten sonra, bunlari Anayasa ile ilgili sanmanın Anayasa'yı anlamamak olduğunu ileri sürdü. Rasih Bey, Peygamberin bile Şam'daki Roma Valisi tarafından kendisine hediye edilen ceketi giydiğini hatırlatarak, "şapka giymekle insan Hıristiyan olmaz. Yahudiler sapka giymişlerdir diye, Hıristiyan mı olmuşlardır? Hisdistan Mecusileri sarık sarıyorlar diye Müslüman mı olmuşlardır?" diyerek kıyafetin dinle ilgisi olmadığını ileri sürdü. Daha sonra Şükrü Kaya, Ragıp ve Necati ve Hakkı Tarık Beyler söz alarak Nurettin Paşa'yı eleştirdiler ${ }^{32}$.

Şapka giyme kanunun kabul edilmesinden bir hafta sonra, Meclis'deki görüişmelerde şapkaya muhalefetinden dolayı ağır sözlerle eleştirilen Nurettin Paşa'ya karşı, basında da saldırılar başlamıştır:

“Millet Meclisi'nde İrtica Paşası'nın İşi Ne? Şapkayı değil fesi, teceddüdü değil taassubu, inkılâbı değil ịrticâyı müdâfaa eden Nurettin Paşa'nın Türk İnkılâp Meclisi'nde yeri yoktur. ${ }^{33}$ ",

Mustafa Kemal Nutuk'da Nurettin Paşa'dan ve faaliyetlerinden uzun uzadiya bahsetmektedir ${ }^{34}$. Ayrica onun şapka kanununa itirâz edip, karşı çıkmasına da büyük tepki göstermiştir ${ }^{35}$.

32. Aybars, İstiklâl Mahkemeleri, C.II, s.400. "Nurettin Paşa'nın bu teklifine verilen sert cevaplar için bkz: Z.C. II/XIX, 25 Kasım 1341(1925), s.250-262.”

33. Cumhuriyet, 2 Kânunıevvel 1341(2 Aralık 1925), No.563.

34. Kemal Atatürk, Nutuk, C.II (1920-1927), Türk Devrim Tarihi Enstitüsü, Milli Eğitim Basımevi, Istanbul, 1972, s.729-749.

35. Mustafa Kemal Nutuk'da; "Efendiler, milletimizin başında, cehil, gaflet ve taasubun ve terakki ve temeddün düşmanlığının alâmet-i fârikası gibi telâkki olunan fesi atarak onun yerine bütün medenî âlemce serpus olarak kullanılan sapkayı giymek ve bu suretle, Türk milletinin, medenî hayat-1 içtimaîyeden, zihniyet itibâriyle de hiçbir fark olmadığını göstermek bir lâzime idi. Bunu Takrir-i Sükûn Kanunu câri olduğu zamanda yaptık. Bu kanun câri olmasaydı, yine yapacaktık. Fakat, bunda, kanunun meriyeti de, sühûlet-bahş oldu denirse, bu, çok doğrudur. Filhakika, Takrir-i Sükûn Kanunu'nun meriyeti, bazı mürtecilerin, milleti vâsi mikyâsta tesmin etmesine meydan birakmamıștır. Gerçi, bir Bursa Mebusu, bütün hayat-1 teşriiysinde, hiçbir vakit kürsüye çıkmamış ve hiçbir vakit Meclis'de, millet ve cumhuriyet menfaatlerini müdâfaa için, bir tek kelime dahi telaffuz etmemiş olan Bursa Mebusu, Nurettin Paşa, yalnız şapka iksâsı aleyhinde, uzun bir takrir vermiş ve bunu müdâfaa için kürsüye çıkmıştır. Şapka iktisâsının 'hukuk-1 esâsiye ve hâkimiyet-i milliye ve masûniyet-i şahsiye hilâfında muâmele' olduğunu iddia 
Şapkanın üstüne, bir de tarikatlann yasaklanması ve tekkelerin kapatılması eklenince, ülkenin birçok yerinde, bunları "dinin elden gitmesi" diye gören tepkiler yükselmiş, Erzurum'da, Maraş'da, Rize'de, Sivas'da, Kayseri'de, Malatya'da şapka aleyhinde bir takım olaylar meydana gelmiştir ${ }^{36}$.

Şapka iktisâsı hakkındaki kanunun TBMM'den çıktığı gün, "Erzurum'da bazı mutaassıpların mürteciyâne bir nümâyiş teşebbüsü"nde bulunduklan, ertesi sabahki gazetelere manşet olmuştur ${ }^{37}$. "Kara kuvvetin uyumadığını gösteren bu hareket derhal bastırılmış ve mütecâsirler yakalanmıştır. Erzurum'da dünden itibâren bir ay müddetle idâre-i örfiye ilân edilmiştir. ${ }^{38}$ ",

Şapka inkılâbına karşı ortaya çıkan bu gibi aleyhte nümâyişler bazı inkılâp düşmanı kişilerin saf-dil Anadolu halkını aldatmasıyla meydana gelmiştir. Nitekim, Erzurum'da sıkıyönetim ilân edilmesi hakkındaki Bakanlar Kurulu kararının TBMM'nce onaylanması görüşülürken, Erzurum Mebusu Rüştü Paşa'nın "eğer münâsip ise bu hususta izâhat verilsin" isteği üzerine, Başvekil İsmet Paşa kürsüye gelerek: "Erzurum'da bir kısım halk çarşıyı kısmen kapatmaya çalışarak, valinin ikâmetgahı önüne gelirler. 'Biz gâvur memur istemeyiz' diye bağırırlar. Nümâyiş yaparlar. Zâbıta müdâhale eder. Zâbitanın ihtârâtına bidâyette itaât etmezler. Bunun üzerine hükümet kuvvetiyle mütecâsirleri dağıtır. Akşama kadar 27 kişi tevkif olunmuştur. Halk umûmiyetle hadiseyi nefretle telâkki etmiştir. Anlaşıldığına göre nümâyişi geçmiş senelerde casuslukla şöhret kazanmış birtakım adamlar yapmışlardır. Bunların içlerinde birtakım şeyhler vardır. Bunlar afv-1 umûmîden istifâde ederek çıkmışlar, şimdi serbest gezerken yeniden faaliyete geçip tertibât almışlardır. Bunların hepsi tevkif olunmuştur. Erzurum Vilâyeti'nin idâre-i örfiye ilân edilmemiş bazı yerleri vardır. Sür'atle ta'kibât yaparak birkaç kişiden ibâret olan mürteb ve müfsidleri meydana çıkarmak, serî icrâat göstermek lâzımdır" demiştir.

İsmet Paşa'nın bu izâhatı üzerine Erzurum'da idâre-i örfiye hakkındaki tezkere kabul edilmiştir ${ }^{39}$.

etmiş ve bunun halka 'adem-i tatbikinin te'mîn ve te'yîd' olunmasına çalışmıştır. Fakat Nurettin Paşa'nın, Millet Kürsüsü'nden galeyana getirmeye muvaffak olduğu taassup ve irticâ hisleri, nihayet bir kaç yerde, yalnız bir kaç mürtecinin, Istiklâl Mahkemeleri'nde, hesap vermeleriyle söndü" derken, bu büyük tepkisini dile getirmektedir. (Nutuk, C.II, s.895-896)

36. Şapka kanununun kabulü üzerine meydana gelen hadiseler hakkında geniş bilgi için bkz: Aybars, İstiklâl Mahkemeleri, C.II, s.406-418; Tunçay, Tek Parti Yönetimi, s. $152-159$.

37. Erzurum hadisesi hakkında bkz: Cumhuriyet, 26 Teşrinisani 1341(26 Kasım 1925), No.557; Mahmut Goloğlu, Devrimler ve Tepkileri (1924-1930), Başnur Matbaası, Ankara, 1972, s.156-157.

38. Cumhuriyet, 26 Teşrinisani 1341(26 Kasım 1925), No.557.

39. Cumhuriyet, 26 Teşrinisani 1341(26 Kasim 1925), No.557; Goloğlu, Devrimler ve Tepkileri, s.156. 
Olayın üçüncü günü, Erzurum Divan-1 Harb-i Örfisi'nin “ilk hükmünü verdiğini" gazetelerden okuyoruz. 114 mevkuftan 3 kişi idama, iki kişi onar seneye mahkûm edilmiştir ${ }^{40}$. Aynı günün gazetelerinde yeni bir olay daha haber verilmektedir. Maraş'da da bir irticâ hadisesi olmuş ve hükümet önüne gelen halk "şapka istemeyiz" diye bağırmışlardır. Bu hadiseler üzerine "Seyyar" Ankara İstiklâl Mahkemesi, süratle hareket etmiş ve olayların çıkmasına sebebiyet verenleri sindirmeye çalışmışırı ${ }^{41}$.

Erzurum'da cereyan eden olayın elebaşılanı Gâvur İmam adında bir hoca ile Hoca Osman adında biri idi. Ve öteki illerde de böyle sınırlı, küçük, tek tük olaylar cereyan etmişti. Hepsinde propoganda; hükümetin dinsizliğe gittiği, kadınların namuslanının zedelendiği şeklinde idi. 14 Kasım'da Sivas'da duvarlara, içinde hükümete hakaret sözleri bulunan bir beyannâme yapıştırılmıştı. Hazırlayanlar, yapıştıranlar ve düşünce birliği yapmış olanlardan 32 kişi mahkûm olmuş, iki kişi sürülmüştü. 2 Kasım'da Kayseri'de; Mekkeli ve Şeyh Sait gibi Nakşibendi olduğunu söyleyerek kışkırtıcılıkta bulunmak isteyen Ahmet Hamdi adında biri, herhangi önemli bir olay çıkmadan yakalanıp mahkemeye verilmişti. 25 Kasım'da Rize'de bir iki hocanın elebaşlığı ile, hükümetin dinsizliğe gitmesini önleme diye bir hareket yapilmak istendiyse de olay derhal bast1rildı, Rize'ye giden İstiklâl Mahkemesi olaya el koydu. 26 Kasım'da Maraş'da; Ibrahim Hoca adında biri, camide başına topladığı bazı kimselerle hükümet aleyhinde gösterilerde bulunmak istedi, fakat hepsi yakalandı ve Ankara'daki İstiklâl Mahkemesi'né gönderildi. 4 Aralık'da Giresun'da; Muharrem adında bir hocanın elebaşılı̆̆ı ile de ötekilere benzer bir hareket yapılmak istenecek ve fakat hemen bastırılarak kovuşturmaya girişilecektir ${ }^{42}$.

Fakat bunlar; toplumca benimsenmiş, desteklenmiş, hoşgörülmüş olaylar değildi. Nitekim; Erzurum'daki elebaşı Hacı Osman'ın, Kayseri'deki Ahmet Hamdi'nin, Giresun'daki Şeyh Muharrem'in buralara yeni gelmiş kimseler olduklarını anlaşılmış olması da bu gerçeği açıkça ve kesinlikle pekiștiriyordu. Halk, bu tür gerici olaylan nefretle karşilıyor ve bu duygularını Ankara'ya gönderdiği telgraflarda açıkça belirtiyordu. Meselâ; Erzurum Belediye Başkanı Nafiz, Müftü Sadık, Halk Partisi Başkanı Ahmet Rıza ve diğer bazı şehir ileri gelenlerinin ortaklaşa imzaladıklan telgrafda şöyle deniliyordu: "Vücutları memleket için şîn olan mahdut bazı rüzalâ tarafından bugün alessabah müessif hâdise zuhur etmiş ise de hükümetimizin tedbir-i sâibesi sayesinde lehülhamd çıktığı anda ve yerde batmıştır.

"Vatanın bir uzvu hayat bahşâsı olup, hükümetimizin mukarrerâtını hürmetle telâkki eden; isyana, fitneye, irticâya karşı nasıl bir nazarı nefre-

40. Cumhuriyet, 29 Teşrinisani 1341 (29 Kasım 1925), No.560.

41. Tunçay, Tek Parti Yönetimi, s. 152. s.156-157.

42. Z.C: II/20, 12 Aralık 1341 (1925), s.109-110; Goloğlu, Devrimler ve Tepkileri, 
ti olduğu ve imhasını nasıl âcil bir vecibe bildiğini hâdise-i ahiredeki canına minnet bildiği hizmeti ile isbât eylemiş olan Erzurum'un pak ve nezih halkı bu hâdise-i elem ve iftiradan dolayı teessürlerini arz ve müsebiblerine lânet eder ve bugün memletimiz nâmına sürülmesi muhtemel lekenin müsebbiblerinin pek ağır bir surette ve esas mürettip ve müşevviklerinin sehpayı adalette çırpınmaları suretiyle silinmesi Erzurumluların en samimi nuhbe-i âmâli olduğunu arz eyleriz. ${ }^{43}$ "

Mustafa Kemal Paşa'nın da her zaman belirttiği ve dirençle anlatmaya çalışığı gibi; halk hiç bir zaman devrimlere karşı olmadığ1 ve devrimleri, karşı olanlan tutmadığı içindir ki; bu tür olaylar genişlemeden, hızla bastırılıp yokedildi ve bir ay gibi kısa bir süre sonunda Erzurum'daki s1kuyönetim kaldırıld ${ }^{44}$.

Burada şu noktayı da belirtmek yerinde olur ki; bu olaylar da mahkûm olanlar, şapka giymedikleri için cezalandırılmamışlardır. Bunlar, şapka giyilmesini protesto ettikleri, buna engel olmak istedikleri ve bu nedenle başkaldırdıkları, ayaklanma teşebbüsünde bulunduklanı için cezalandırılmışlardır ${ }^{45}$.

Ağustos 1925 sonunda Mustafa Kemal, Kastamonu'da; “yaptığımız ve daha da yapacağımız devrimlerin hedefi, Türkiye Cumhuriyeti halkı$\mathrm{n} ı$ tamamı ile modern ve tam anlamı ve bütün şekilleriyle medenî bir toplum haline getirmektir" diye açıklamıştı. "Medenî dünyanın milletleraras1 kılığı"nı ve özellikle şapkayı bunlar arasında sayıyordu. Bakanlar Kurulu'nun 2 Eylül 1925 tarihli bir kararnâmesi, ordu ve donanma mensuplan ile ulemânın ve hâkimlerin dışındaki -Bunlar için özel nizâmlar konulacaktı- bütün memurlar için "medenî dünyada" genel olarak kullanılan kılığı: elbise ve şapkayı, zorunlu kılıyordu. Halk buna uymak ya da uymamakta serbestti. Aynı günlerde çıkan ikinci bir kararnâme din adamları için beyaz sarık ve siyah latayı kabul ediyordu; ordudaki imamların sarık ve cübbelerinin rengí askerliğin gereklerine uyacaktı. Din adamlarına, görevleri dışında sivil elbise giymek müsaadesi veriliyordu. Din adamı olmayanların dini kılıkta gezmeleri yasak edilmişti. Bunun aksine davranışlar bir yıla kadar hapisle cezalandırılacaktı. Önce halkı, bu yolda memurlara uymaya teşvikle yetinilirken, 25 Kasım 1925 tarihli kanunla s. 157 .

43. Z.C: II/19, 25 Kasım 1341(1925), s.219-220; Goloğlu, Devrimler ve Tepkileri,

44. Z.C: II/20, 24 Aralık 1341(1925), s.252; Goloğlu, Devrimler ve Tepkileri, s. 157-158. Erzurum ve civarında uygulanmakta olan sıkıyönetimin son bulduğu hakkında Başbakanlık tarafından Büyük Millet Meclisi Başkanlığı'na verilen tezkere şöyle idi:

'Büyük Millet Meclisi Riyâseti'ne

Yirmidört Teşrinisanide bir ay müddetle Erzurum ve civarında ilân olunan idâre-i örfiyenin hitâm bulmus olduğunu beyân-1 malûmat arz ederim efendim." (Z.C: II/20, 24 Aralık 1341(1925), s.252).

45. Goloğlu, Devrimler ve Tepkileri, s.158. 
bu zorunluluk şeklini aldı: "Türk milletinin umûmî serpuşu şapkadır ve hükümet buna karşı olan geleneğin devamını meneder." Bundan sonra fes giyenler, eğer halkı isyana teşvik ya da devlet kuvvetlerine karşı direnmekle suçlanmazlarsa, "kanun ve nizâmlara göre, yetkili makamlan tarafından verilmiş emre itaatsizlik suçundan", bir aya kadar hapisle cezalandirilabiliyorlardi ${ }^{46}$.

Böylece fese bir kutsallık veren, onu çıkanı atmayı, mukaddesâta hakaret sayan sakat bir zihniyet bertaraf edilerek, 25 Kasım 1925 tarihli kanunla milletlerarası kılık kıyafet kabul edilmiş oluyordu.

46. Gotthard Jaeschke, Yeni Türkiye'de İslâmlık, Bilgi Basımevi, Ankara, 1972, s.28-29. 